\title{
PENYELESAIAN TINDAK PIDANA BIASA BERMOTIF RINGAN DENGAN RESTORATIF JUSTICE SEBAGIAN BENTUK UPAYA PEMBAHARUAN HUKUM PIDANA
}

\author{
Herlina Manullang ${ }^{1}$, Ranap Sitanggang ${ }^{2}$, Sumangat Sidauruk $^{3}$, Erwin Sinaga ${ }^{4}$ \\ Program Studi Magister Hukum \\ Program Pascasarjana \\ Universitas HKBP Nommensen, Medan-Sumatera Utara-Indonesia \\ e-mail: herlinamanullang63@gmail.com
}

\begin{abstract}
Ordinary criminal acts are mildly motivated, tend to be like ordinary criminal acts, this is due to law enforcement officials only emphasizing the criminal liability aspect of the offender whose emphasis is on the ability to be held accountable and wrong, regardless of the quality of the actions and the value of the object of loss from infringement inflicted. The nature of ordinary criminal offenses with mild motives is ordinary criminal acts which are of a simple nature, harmless and the losses experienced by victims are relatively smaller. Therefore, the handling of ordinary crimes with mild motives needs to be done with a restorative justice approach, which is an approach that focuses more on the principle of justice and balance (recovery) between perpetrators and victims. The research method used in this study is based on normative jurisdiction with an approach that is based on the statute approach and case approach. The handling of ordinary crimes with mild motives can be carried out if the conditions / criteria for restorative justice have been met, among others, the perpetrator has acknowledged his actions, the victim and / or the victim's family wishes to forgive the offender and the community supports the deliberation and meets the qualifications of minor criminal offenses. fulfilled, the police can carry out a restorative justice approach through a criminal mediation forum in the mediation room during the investigation process, with the aim of restoring the perpetrators, victims and the community. If mediation and deliberation can give rise to an agreement, it can be done as a reason for criminal offense for ordinary criminal offenders with a motive pattern and continued by the perpetrators to recover the losses incurred, of course this causes the minor criminal cases to be completed without the need to be brought to court.
\end{abstract}

Keywords : Settlement of criminal acts, Restorative Justice, and Criminal Law Reform

\begin{abstract}
Abstrak
Penanganan tindak pidana biasa bermotif ringan, cenderung seperti tindak pidana biasa, hal ini disebabkan aparat penegak hukum hanya menekankan kepada aspek pertanggungjawaban pidana pelaku yang penekananya kepada kemampuan bertanggungjawaban dan kesalahan, tanpa melihat kualitas dari perbuatan dan nilai obyek kerugian dari pelanggaran yang ditimbulkan. Sifat tindak pidana biasa bermotif ringan adalah tindak pidana biasa yang sifatnya sederhana, tidak berbahaya dan kerugian yang dialami korban relatif lebih kecil. Oleh karena itu penaganan tindak pidana biasa bermotif ringan perlu dilakukan dengan pendekatan restorative justice, yaitu pendekatan yang lebih menitik beratkan kepada prinsip keadilan dan keseimbangan (pemulihan) antara pelaku dan korban. Metode penelitian yang digunakan dalam penelitian ini adalah di dasarkan kepada yuridis normatif dengan pendekatan yang di dasarkan kepada_pendekatan perundang-undangan (statute approach) dan pendekatan kasus (case approach). Penanganan tindak pidana biasa bermotif ringan dapat dilakukan apabila
\end{abstract}


syarat-syarat/kriteria restorative justice telah terpenuhi antara lain pelaku telah mengakui perbuatannya, korban dan atau keluarga korban berkeinginan untuk memaafkan pelaku serta komunitas masyarakat mendukung musyawarah dan memenuhi kualifikasi tindak pidana ringan, apabila hal tersebut telah terpenuhi maka aparat kepolisian dapat melakukan pendekatan restorative justice melalui forum mediasi penal diruang mediasi selama dalam proses pemeriksaan, dengan tujuan pemulihan bagi pelaku, korban dan masyarakat. Jika mediasi dan musyawarah dapat melahirkan kesepakatan hal tersebut dapat dilakukan sebagai alasan penghapus pidana bagi pelaku tindak pidana biasa bermotif ringan dan dilanjutkan oleh pelaku untuk memulihkan kerugian yang ditimbulkannya, tentu saja hal ini menyebabkan perkara tindak pidana ringan tersebut selesai tanpa perlu diajukan ke pengadilan.

Kata Kunci : Penyelesaian Tindak Pidana, Restorative Justice dan Pembaharuan Hukum Pidana

\section{A. Pendahuluan}

Hukum, adalah rangkaian peraturan mengenai tingkah laku orang-orang sebagai anggota masyarakat; sedangkan satu satunya tujuan dan hukum ialah mengadakan keselamatan, kebahagian, dan tata tertib di dalam masyarakat. Dan masing-masing masyarakat mempunyai pelbagai kepentingan yang beraneka warna dan yang dapat menimbulkan bentrokan satu sama lain. Jika bentrokan terjadi, maka masyarakat menjadi terguncang dan keguncangan ini mesti dihindari. Untuk itulah hukum menciptakan pelbagai hubungan tertentu dalam masyarakat. ${ }^{1}$

Menurut Sudarto bahwa hukum pidana adalah perbuatan yang dapat dikenakan hukuman (pidana) dan macam-macam hukuman yang dapat dijatuhkan. Pidana adalah penderitaan yang sengaja dibebankan kepada seorang yang melakukan perbuatan yang memenuhi syarat tertentu. ${ }^{2}$

Selanjutnya Moelyatno menyatakan bahwa : Hukum adalah bagian dari pada keseluruhan hukum yang berlaku di suatu negara yang mengadakan dasar-dasar dan aturanaturan untuk: ${ }^{3}$

1. Menentukan perbuatan-perbuatan mana yang tidak boleh dilakukan, yang dilarang, dengan disertai ancaman atau sanksi yang berupa pidana tertentu bagi barang siapa melanggar larangan tersebut;

2. Menentukan kapan dan dalam hal hal apa kepada mereka yang telah melanggar larangan-larangan itu dapat dikenakan atau dijatuhi pidana sebagaimana yang telah diancamkan;

3. Menentukan dengan cara bagaimana pengenaan pidana itu dapat dilaksanakan apabila ada orang yang disangka telah melanggar larangan tersebut.

Mekanisme hukum acara pidana dan sistem pemidanaan di Indonesia mengacu kepada Undang-Undang No 8 Tahun 1981 secara formal mengatur tentang prosedur penyelesaian perkara pidana. Menurut prosedur hukum acara pidana dimulai dari penyelidikan dan penyidikan di tingkat Kepolisian, penuntutan oleh Jaksa Penuntut Umum di persidangan dan putusan pengadilan atau vonis hakim pengadilan. Proses tersebut memerlukan waktu yang tidak praktis dan memerlukan waktu yang lama.

Dalam pratik hukum acara pidana dikenal dengan istilah Tindak Pidana Ringan (Tipiring), istilah ini merupakan singkatan yang terdapat di dalam Kitab Undang-Undang

\footnotetext{
${ }^{1}$ Wirjono Prodjodikoro, Asas-Asas Hukum Acara Pidana di Indonesia, Cet ke 3 Bandung, Erisco, 1989, hal 14.

${ }^{2}$ Sudarto, Hukum Pidana, 1975, hal17

${ }^{3}$ Moelyatno, Asas-Asas Hukum Pidana, Cet ke 6,Jakarta, Rineka Cipta, 20oo, hal 1
} 
http://ejournal.uhn.ac.id/index.php/opinion

Hukum Acara Pidana, BAB XVI, Pemeriksaan di Sidang Pengadilan, Bagian ke enam Acara Pemeriksaan Tindak Pidana Ringan. Di dalam Peraturan Mahkamah Agung Republik Indonesia No 02 Tahun 2012 Tentang Penyesuaian Batasan Tindak Pidana Ringan dan Jumlah Denda dalam KUHP menyatakan bahwa :

"Pasal 1, kata-kata "dua ratus lima puluh rupiah" dalam Pasal 364, Pasal 373, Pasal 379, Pasal 384, Pasal 407 dan Pasal 482 KUHP, dibaca menjadi Rp. 2.500.000,00 (dua juta lima ratus rupiah);

Pasal 2, Apabila nilai barang atau uang tersebut bernilai tidak lebih dari Rp 2.500.00o,oo (dua juta lima ratus rupiah) Ketua Pengadilan segera menetapkan Hakim Tunggal untuk memeriksa, mengadili dan memutus perkara tersebut dengan acara pemeriksaan cepat yang diatur dalam Pasal 205-210 KUHAP;

Apabila terhadap terdakwa sebelumnya dikenakan penahanan, Ketua Pengadilan tidak menetapkan penahanan ataupun perpanjangan penahanan".

Setelah dikeluarkannya Peraturan Mahkamah Agung tersebut, pada bulan Oktober 2012 Mahkamah Agung bersama-sama dengan Kejaksaan Republik Indonesia, Kepolisian Republik Indonesia dan Kementerian Hak Asasi Manusia (Kemenkumham) telah membuat Nota Kesepakatan Bersama terkait pelaksanaan Peraturan Mahkamah Agung Nomor 2 Tahun 2012 tentang Penyesuaian Batasan Tindak Pidana Ringan dan Jumlah Denda Dalam Kitab UndangUndang Hukum Pidana (KUHP). Di dalam Nota Kesepakatan Bersama tersebut menegaskan bahwa terhadap perkara tindak pidana ringan dapat diselesaikan dengan menggunakan restorative justice (pemulihan keadilan). ${ }^{4}$

Meskipun telah dikeluarkannya Nota Kesapahaman Bersama terkait dengan pelaksanaan Peraturan Mahkamah Agung Nomor 2 Tahun 2012, penaganan perkara tindak pidana ringan di Indonesia secara terus menerus telah menarik banyak perhatian masyarakat dan simpati ketidak puasan terhadap aparat penegak hukum, sebagai contoh kasus nenek Minah atau Asyani dan kasus kasus lainnya yang terekam masyarakat.

Ketidak puasan masyarakat terhadap aparat penegak hukum terutama Kepolisian adalah disebabkan Polri lebih menekankan kepastian hukum dibandingkan tujuan hukum lainnya yaitu keadilan dan kemanfatan. Dalam penulisan ini yang menjadi persoalan adalah bagaimanakah penyelesaian tindak pidana ringan melalui restorative justice dapat dilakukan? serta Bagaimanakah model alternatif yang dapat dilakukan dalam penyelesaian tindak pidana biasa bermotif ringan sebagai upaya pembaharuan hukum pidana?

\section{B. Metode Penelitian}

Jenis penelitian yang digunakan dalam penelitian ini adalah penelitian hukum normatif atau penelitian doktrinal. ${ }^{5}$ Sesuai dengan jenis penelitian hukum normatif ini maka pendekatan yang digunakan adalah pendekatan perundang-undangan (statute approach) dan pendekatan kasus (case approach). Dua macam pendekatan ini dilakukan untuk menemukan sebanyak mungkin informasi yang sedang diteliti agar dapat dianalisis guna memecahkan masalah yang telah ditetapkan. Sifat penelitian ini adalah bersifat perspektif yaitu menjawab permasalahan yang telah ditetapkan sebelumnya. Sifat perspektif suatu penelitian adalah terdapatnya sifat penelitian yang problematik yang memerlukan pemecahan masalah (problem solving). Selain menggambarkan masalah perlu juga diberi jalan keluar untuk penanggulangan masalahnya. Sehingga jawaban yang diperoleh dari problem solving tersebut akan menjadi

\footnotetext{
4 http://www.hukumonline.com/berita/baca/lt524025679ffe/ma-keluhkan-pelaksanaan-perma-tipiring, diakses pada hari Kamis, Tanggal 18 Juni 2020, Jam 22.30.

${ }^{5}$ Suratman dan Philips Dillah, 2013, Metode Penelitian Hukum, Alfabeta, Bandung, hal.31.
} 
Jurnal Magister Hukum Program Pascasarjana Universitas HKBP Nommensen

Volume or Nomor o1 Juli 2020 Halaman. 64-77

e-ISSN: 2723-164X p-ISSN: 2722-9858

http://ejournal.uhn.ac.id/index.php/opinion

sesuatu yang baru (something new) kepada pihak yang terkait. ${ }^{6}$ Sumber bahan hukum yang digunakan dalam penelitian ini berupa bahan hukum primer, bahan hukum sekunder dan Bahan hukum tersier .

\section{Pembahasan}

\section{Karakteristik Tindak Pidana Ringan di Indonesia dan Perkembangannya}

Karakteristik tindak pidana ringan (Tipiring) adalah tindak pidana yang bersifat ringan atau tidak berbahaya. Oleh karena sifatnya yang tidak berbahaya maka penyelesaian perkara tindak pidana ringan dapat dilakukan dengan Acara Pemeriksaan Cepat. Pelaksanaan acara pemeriksaan ringan dalam penaganan tindak pidana ringan dalam dilakukan dengan prosedur yang lebih sederhana, hal ini dapat dilihat dari karakteristik acara pemeriksaan cepat yang memiliki beberapa ketentuan khusus, yaitu;

1. Dalam hal yang berfungsi sebagai penuntut adalah penyidik atau kuasa penuntut umum, bahwa pengertian "atas kuasa" ini adalah "demi hukum";

2. Tidak dibuat surat dakwaan, karena yang menjadi dasar pemeriksaan adalah catat dan berkas yang dikirimkan oleh penyidik ke pengadilan;

3. Saksi tidak mengucapkan sumpah atau janji, kecuali apabila hakim menganggap perlu.

Tindak pidana ringan tidak hanya sebatas pelanggaran saja tetapi juga mencakup kejahatan-kejahatan yang diatur di dalam Buku II KUHP yang terdiri dari; penganiayaan hewan ringan, penghinaan ringan, penganiyaan ringan, pencurian ringan, penggelapan ringan, penipuan ringan, perusakan ringan dan penadahan ringan. Sistematika KUHP bahwa tindak pidana hanya terdiri dari kejahatan (misdrijven) dan pelanggaran (overtredigen). Akan tetapi memperhatikan pasal pasal di dalam KUHP ternyata Buku II tentang kejahatan juga terdapat sejumlah tindak pidana yang dapat dikelompokkan sebagai kejahatan ringan (lichte misdijven). Tindak pidana ringan ini tidak ditempatkan dalam satu bab tersendiri melainkan letaknya tersebar pada berbagai bab di dalam buku II KUHP.

Beberapa jenis tindak pidana ringan berdasarkan pasal-pasal dalam KUHP yang tergolong sebagai tindak ringan antara lain :

1. Pasal 302 ayat (1) KUHP bahwa diancam dengan pidana penjara paling lama 3 bulan atau pidana denda paling banyak $\mathrm{Rp}$ 4500,- karena melakukan penganiayaan ringan terhadap hewan;

Barang siapa tanpa tujuan yang patut atau secara melampaui batas, dengan sengaja menyakiti atau melukai hewan atau merugikan kesehatannya :

Barang siapa tanpa tujuan yang patut atau dengan melampaui batas yang diperlukan untuk mencapai tujuan itu, dengan sengaja tidak memberi makanan yang diperlukan untuk hidup kepada hewan, yang seluruhnya atau sebagaian menjadi kepunyaannya da nada dibawah pengawasannya, atau kepada hewan yang wajib dipeliharanya. ${ }^{7}$

2. Pasal 315 KUHP, bahwa tiap tiap penghinaan dengan sengaja yang tidak bersifat pencemaran atau pencemaran tertulis yang dilakukan terhadap seseorang, baik dimuka umum dengan lisan atau tulisan, maupun dimuka orang itu sendiri dengan lisan atau perbuatan, atau dengan surat yang dikirimkan atau diterimakan kepadanya, diancam karena penghinaan ringan dengan pidana penjara paling lama empat bulan dua minggu atau pidana denda paling banyak empat ribu lima ratus rupiah.

Unsur utama dari pencemaran di dalam Pasal 310 KUHP adalah pelaku itu "menuduhkan sesuatu hal". Pada Pasal 310 ayat (1) ditentukan bahwa barang siapa

\footnotetext{
${ }^{6}$ Solly Lubis, 2012, Filsafat Ilmu dan Penelitian, Sofmedia, Medan, hal.121

${ }^{7}$ R.Soesilo, 1998, Kitab Undang-Undang Hukum Pidana (KUHP) Serta Komentar-Komentarnya Lengkap Pasal Demi Pasal, Politea Bogor, Hal.252,
} 
sengaja menyerang kehormatan atau nama baik seseorang dengan menuduhkan sesuatu hal, yang maksudnya terang supaya hal itu diketahui umum, diancam karena pencemaran. Ciri khas penghinaan ringan dilakukan seperti menggunakan kata-kata kasar yang ditujukan kepada orang lain, seperti memaki-makai orang tersebut. ${ }^{8}$

3. Pasal 352 ayat (1) KUHP, penganiyaan ringan. Di dalam Pasal 352 ayat (1) KUHP ditentukan kecuali tersebut dalam Pasal 353 dan Pasal 356 KUHP, maka penganiayaan yang tidak menimbulkan penyakit atau halangan untuk menjalankan pekerjaan jabatan atau pencarian, diancam, sebagai penganiayaan ringan, dengan pidana penjara paling lama tiga bulan atau pidana denda paling banyak empat ribu lima ratus rupiah. Yang membedakan penganiayaan ringan dengan penganiayaan biasa adalah bahwa penganiyaan ringan terhadap korban tidak timbul penyakit atau (halangan untuk menjalankan pekerjaan jabatan atau pencarian. ${ }^{9}$

4. Pasal 364 KUHP, pencurian ringan. Pencurian ini dikategorikan sebagai pencurian ringan apabila pencurian yang dilakukan oleh dua orang atau lebih yang nilai harga barangnya tidak lebih dari Rp.250,-- Pencurian yang meskipun harga barang yang dicuri tidak lebih dari $\mathrm{Rp}$ 250,- juga tidak bisa dikategorikan pencurian ringan, yaitu pencurian hewan (Pasal 363 sub 1 KUHP) pencurian pada waktu kebakaran dan malapetaka lain (Pasal 363 sub 2 KUHP), pencurian waktu malam di dalam rumah atau pekarangan tertutup yang ada rumahnya oleh orang yang ada disitu tidak dengan setahunya atau kemauannya orang yang berhak (Pasal 363 sub 3 KUHP, dan pencurian dengan kekerasan (Pasal 365 KUHP). ${ }^{10}$

5. Pasal 373 KUHP, penggelapan ringan adalah suatu tindak pidana dikatakan masuk dalam kategori penggelapan ringan apabila nilai barang yang digelapkan tidak lebih dari Rp 250,-."

6. Pasal 379 KUHP, penipuan ringan adalah suatu tindak pidana dikategorikan penipuan ringan apabila barang yang diberikan itu bukan hewan dan barang, utang atau piutang itu tidak lebih dari Rp.250,-

7. Pasal 384 KUHP, penipuan ringan adalah apabila penipuan ringan oleh penjual bahwa harga keuntungan yang diperoleh tidak lebih dari Rp. 250,- ${ }^{12}$.

8. Pasal 407 KUHP, perusakan ringan adalah perusakan barang yang tersebut dalam Pasal 406 KUHP saja (Pasal 408 KUHP, 409 KUHP, 410 KUHP tidak bisa) yaitu apabila harga kerusakan itu tidak lebih dari Rp.250,- dan apabila binatang yang dibunuh itu bukan hewan sebagaimana yang tersebut dalam Pasal 101 KUHP, dan tidak dipergunakan zat yang membahayakan nyawa atau kesehatan. ${ }^{13}$

9. Pasal 482 KUHP, perbuatan penadahan ringan dikategorikan apabila barang yang diperoleh karena salah satu kejahatan yang diterangkan dalam Pasal 364, Pasal 373 dan Pasal 379 KUHP. Hal ini merupakan kejahatan sekongkol ringan. Perbuatan yang termasuk dalam hal ini adalah perbuatan yang tersebut dalam Pasal 48o KUHP, yang mengatur tentang tindakan persekongkolan. Barang-barang yang diterima karena sekongkol itu harus berasal dari kejahatan ringan, seperti pencurian ringan (Pasal 364 KUHP), penggelapan ringan (Pasal 373 KUHP) dan penipuan ringan (Pasal 379 KUHP).

\footnotetext{
${ }^{8}$ Ibid

${ }^{9}$ Ibid

${ }^{10}$ Ibid

${ }^{11}$ Ibid

${ }^{12}$ Ibid

${ }^{13}$ Ibid
} 
Jadi ukuran yang ditetapkan disini bukanlah harga barang yang diterimanya, akan tetapi sifat dari kejahatan itu. ${ }^{14}$

Dalam perkembangnya, telah dikeluarkan Peraturan Mahkamah Agung (PERMA) Nomor 2 Tahun 2012 tentang Penyesuaian Batasan Tindak Pidana Ringan dan jumlah denda dalam KUHAP. Sebagai tindak pidana dari PERMA, telah dibentuk Nota Kesepakatan Bersama (Nokerber) No 131/KMA/SKB/X/2012; No M.HH,07.HM.03.02 Tahun 2012; Nomor:KEPo6/E/EJP/10/2012; Nomor: B/39/X/2012, Rabu tanggal 17 Oktober 2012 tentang Pelaksanaan Penerapan Penyusunan Batasan Tindak Pidana Ringan dan Jumlah Denda, Acara Pemeriksaan Cepat serta Penerapan Keadilan Restorative Justice (Restoratif Justice). Berdasarkan pengaturan dalam Nota Kesepahaman Bersama (Nokesbar) di atas, dapat diperoleh beberapa hal, antara lain: Pasal 1 ayat (1) Nokesbar bahwa "Tindak Pidana Ringan adalah tindak pidana yang diatur dalam Pasal 364, 373, 379, 384, 407 KUHP dan Pasal 482 KUHP yang diancam dengan pidana penjara paling lama 3 (tiga) bulan atau denda 10.000 (sepuluh ribu) kali lipat dari denda"

\section{Pemikiran Restoratif Justice Dalam Penyelesaian Tindak Pidana}

Latar belakang pemikiran mengenai Restorative Justice atau yang lebih dikenal sebagai keadilan Restoratif adalah merupakan reakasi yang diberikan oleh para ahli hukum pidana akan nampak negatif dari penerapan hukum pidana yang memiliki sifat represif atau koersifnya. Dengan mengkaji dampak negatif dari penerapan hukum pidana, para ahli pidana telah menggagas keadilan restoratif untuk menggantinya sebagai sarana reparatif.

Dalam sejarahnya, pemikiran tentang keadilan restoratif muncul dari gerakan abolisionis yang ingin menggantikan hukum pidana sebagai sarana lain untuk menanggulangi pidana. Menurut Louk Hulsman sebagaimana dikutip oleh G. Widiartana, bahwa sistem hukum pidana dibangun berdasarkan pikiran hukum pidana yang harus menimbulkan nestapa. Pikiran yang demikian menurut Louk Hulsman sangat berbahaya. Oleh sebab itu Louk Hulsman mempunyai ide untuk menghapus sistem hukum pidana yang dianggap telah mendatangkan penderitaan daripada kebaikan dengan cara-cara yang lebih baik. Pikiran Louk Hulsman jika dirunut lebih jauh, bahwa pikiran kaum abolisionis tentang restorative justice dipengaruhi pikiran pikiran revolusioner kriminolog yang tidak puas akan pendekatan kriminologie klasik. ${ }^{15}$

Restorative Justice merupakan suatu respon terhadap tindak pidana yang menitik beratkan pada pemulihan korban yang menderita kerugian, memberikan pengertian kepada pelaku pidana yang mereka lakukan, dan membangun masyarakat yang damai. Restorative Justice dapat digambarkan sebagai suatu tanggapan kepada perilaku kejahatan untuk memulihkan kerugian yang di derita para korban kejahatan dan memudahkan perdamaian antar pihak-pihak yang saling bertentangan.$^{16}$

Kelompok Kerja Peradilan Anak Perserikatan Bangsa-Bangsa (PBB) mendefinisikan restorative justice sebagai suatu proses semua pihak yang berhubungan dengan tindak pidana tertentu duduk bersama-sama untuk memecahkan masalah dan memikirkan bagaimana mengatasi akibat pada masa yang akan datang. Proses ini pada dasarnya dilakukan melalui diskresi (kebijakan) dan diversi (pengalihan dari proses pengadilan pidana ke luar proses formal untuk diselesaikan secara musyawarah). ${ }^{17}$

\footnotetext{
${ }^{14}$ Ibid

${ }^{15}$ G. Wediartana, 2014, Viktimologi Perspektif Korban Dalam Penanggulangan Kejahatan, Cahaya Atma Pustaka, Yogyakarta, hal 141.

${ }^{16}$ Kevin I.Minor and J.T Morrison, 1996, A Theoretical Study and Critique of Restorative Justice" In Restorative Justice; International Perspective, edited by Burt Galaway and Joe Hudson; Criminal Justice Press and Kugler Publications, The Netherlands, page.117.

${ }^{17}$ Retna Yuli, 2010, Viktimologi Perlindungan Hukum Terhadap Korban Kejahatan, Graha Ilmu, Bandung, hal.164.
} 
http://ejournal.uhn.ac.id/index.php/opinion

Menurut Tony F. Marshall, "Restorative justice is a process whereby all the parties with a stake in a particular offence come together to resolve collectively how to deal with the aftermath of the offence and its implications for the future" ${ }^{18}$ (Restorative justice adalah sebuah proses dimana semua pihak yang berkepentingan dalam pelanggaran tetentu bertemu bersama untuk menyelesaikan secara bersama-sama untuk menyelesaikan secara bersama-sama begaimana menyelesaikan akibat dari pelanggaran tersebut demi kepentingan masa depan). Selanjutnya M. Cherif Bassiouni menegaskan bahwa kita tahu dan tidak pernah tahu secara pasti metodemetode tindakan (treatment) apa yang paling efektif untuk mencegah dan memperbaiki atau kita pun tidak mengetahui seberapa jauh efektivitas setiap metode tindakan itu. Untuk dapat menjawab masalah-masalah ini secara pasti, harus mengetahui sebab sebab kejahatan dan untuk mengetahui tersebut di perlukan pengetahuan mengenai etilogi tingkah laku manusia. ${ }^{19}$

Berdasarkan defenisi tersebut di atas bahwa restorative justice adalah wahana untuk memperbaiki korban, pelaku dan masyarakat akibat adanya kejahatan. Sehingga dengan mengunakan Restorative justice lebih mengutamakan terjadinya kesepakatan antara pihak yang berpekara dan berkeja keras untuk terjaminnya keadilan, restorasi kehormatan, menumbuhkan budaya malu, penyembuhan terhadap korban dan hal-hal lainnya. Maka dengan demikian restorative justice adalah program yang menjanjikan dalam strategi mereduksi kejahatan. Oleh sebab itu restorative justice harus dibangun secara dinamis dan menciptakan tatanan yang dipergunakan sebagai pedoman. ${ }^{20}$

\section{Model Penyelesaian Tindak Pidana Ringan Melalui Restorative Justice di Masa Depan}

Konsep Keadilan Restoratif (Restorative Justice) telah muncul lebih dari dua puluh tahun yang lalu sebagai alternative penyelesaian perkara pidana anak. Penyelesaian melalui restorative atau musyawarah sebetulnya bukan hal baru bagi Indonesia, bahkan hukum adat di Indonesia tidak membedakan penyelesaian perkara pidana dan perdata, semua perkara dapat diselesaikan secara musyawarah dengan tujuan untuk mendapatkan keseimbangan atau pemulihan keadaan hukum pidana secara represif dirasakan tidak menyelesaikan persoalan dalam sistem hukum peradilan pidana.

Lahirnya gagasan tentang konsep restorative justice atau keadilan restorative sebagai bentuk penyelesaian alternatif, muncul sebagai respon terhadap kinerja sistem peradilan pidana antara lain :

1. Yang bertindak untuk penyelesaian perkara adalah aparat hukum (Kepolisian, Kejaksaan, Pengadilan, Lembaga Pemasayarakatan) yang mengatasnamakan negara untuk kepentingan umum/masyarakat (korban), pengacara/advokat atas nama pelaku, tanpa pelibatan masyarakat, pelaku, korban secara langsung atau tanpa peran aktif para pihak yang bersangkut paut dengan tindak pidana tersebut untuk menyelesaikan masalahnya sendiri;

2. Bahwa hasil putusannya (output) lebih cenderung bersifat pembalasan atau penghukuman dari pada memberikan putusan yang bersifat "win-win-solution" (menguntungkan kedua belah pihak sesuai kehendak para pihak) sesuai dengan kehendak para pihak:

3. Keadilan yang dirasakan bersifat retributive (menekankan keadilan dan pembalasan) dan restituve (keadilan yang menekankan atas dasar ganti rugi), dan tidak memikirkan jalan untuk memberikan restorative justice yang dapat dirasakan secara menyeluruh oleh semua pihak yang berkepantingan (stakeholders).

\footnotetext{
${ }^{18}$ Marlina , 2010, Hukum Penitensier, .....hal 28.

${ }^{19}$ Barda Nawawi Arief, 1996.

${ }^{20}$ Retna Yuli, Opcit, hal 161.
} 
http://ejournal.uhn.ac.id/index.php/opinion

Sasaran akhir konsep peradilan restorative ini mengharapkan berkurangnya jumlah tahanan di dalam penjara; menghapuskan stigma atau cap dan mengembalikan pelaku kejahatan menjadi manusia normal; pelaku kejahatan dapat menyadari kesalahannya, sehingga tidak mengulangi perbuatannya serta mengurangi beban kerja polisi, jaksa, rutan, pengadilan, dan lembaga pemasyarakatan, menghemat keuangan negara, tidak menimbulkan rasa dendam karena pelaku telah dimaafkan oleh korban, korban cepat mendapatkan ganti kerugian; memberdayakan masyarakat dalam mengatasi kejahatan dan pengintegrasian kembali pelaku kejahatan dalam masyarakat.

Mekanisme dan tata cara peradilan pidana yang berfokus pada pemidanaan diubah menjadi proses dialog dan mediasi menciptakan kesepakatan atas penyelesaian perkara pidana yang lebih adil dan seimbang baik bagi korban maupun pelaku. Restorative justice memiliki makna keadilan yang merestorasi. Di dalam peradilan pidana saat ini dikenal adanya restitusi atau ganti rugi terhadap korban, sedangkan restorasi memiliki makna yang lebih luas.

Pada dasarnya ada empat tipe penyelesaian perkara melalui upaya restorative justice yang digunakan di beberapa negara, adapun penjelasan dari masing-masing tipe restorative justice antara lain : ${ }^{21}$

1. Victim-Offender Mediation adalah tipe penyelesaian yang paling sederhana dan yang pertama kali diterapkan ketika terjadi kasus pengerusakan di Kanada pada Tahun 1974 yang menjadi cikal bakal restorative justice, penyelesaian ini mengedapankan pertemuan keinginan dari korban dan pelaku, yang dalam hal ini korban hendak kerugiannya terpulihkan sementara pelaku memiliki keinginan untuk tidak dihukum. Untuk mempertemukan keinginan antara korban dan pelaku itulah maka diupayakan mediasi, dalam perkembangannya mediasi tersebut dilakukan secara langsung dengan mempertemukan antara korban dan pelaku ataupun melalui kuasa hukum dari masing-masing pihak. Dalam mediasi ini peran keluarga para pihak sama sekali tidak ada, keluarga para pihak tidak boleh mengajukan ide ataupun usulan, semuanya mutlak bersumber dari para ppihak baik korban maupun pelaku, para kuasa hukum hanya perpanjangan tangan dari keinginan para pihak yang tidak ingin bertemu, buka penentu keputusan ataupun sebagai pihak yang melakukan tawar menawar. Sistem ini diterapkan di Amerika Serikat dan Inggris.

2. Family Group Conferencing merupakan tipe penyelesaian yang mirim dengan Victim Family Group Conferencing merupakan tipe penyelesaian ini mirip dengan VictimOffender mediation, akan tetapi dalam hal ini peranan keluarga korban dan pelaku lebih dominan ketika menentukan syarat-syarat perdamaian, jika dalam tipe pertama para pihak amat berperan dalam menentukan perdamaian, maka dalam tipe ini para keluargalah yang lebih dominan peranannya. Hal ini dikarenakan beberapa alasan yaitu dimungkinkan adanya perasaan shock ataupun kaget dari korban akibat perbuatan pelaku yang menyebabkan korban tidak dapat berpikir jernih dan hal ini dapat dimanfaatkan pelaku untuk menentukan syarat-syarat perdamaian. Sebaliknya dari pihak pelaku ada kalanya pelaku tidak dapat berpikir jernih, hal ini dikarenakan adanya tekanan dari korban atau intimidasi atau bisa jadi kondisi psikis pelaku yang terancam akan di hukum, yang semuanya dapat menjadikan pelaku tereksploitasi secara tidak terkontrol oleh korban. Untuk menghindari hal-hal yang tidak diinginkan tersebut maka peranan keluarga amatlah diperlukan, mengingat keluarga bukanlah korban yang menderita langsung ataupun bukanlah pelaku yang melakukan langsung tindak pidana tersebut, sehingga kemungkinan-kemungkinan rasa takut, kaget atau

\footnotetext{
${ }^{21}$ John M.Scheb JD dan John M.Scheb II, 2008, Criminal Law and Procedure, Sixt Edition, Thomson Laerning, Belmont, p 6-7.
} 
shock tidak akan mungkin terjadi. Maka dapat ditemukan suatu titik temu yang membawa kebaikan bagi kedua belah pihak baik korban ataupun pelaku, sehingga dapat memang benar-benar memenuhi rasa keadilan. Hal ini muncul dikarenakan pada beberapa kasus, korban adakalanya tidak dapat berpikir jernih, sehingga ada kalanya korban kerugian tidak terpulihkan secara maksimal dikarenakan dipermainkan oleh pelaku yang mengetahui korban tidak dapat berpikir jernih. Sementara itu pelaku ada kalanya ditekan oleh korban, sehingga terpaksa mengganti kerugian melebihi yang seharusnya diganti oleh pelaku. Untuk mencegah hal inilah makanya diperlukan para pihak yang sama-sama dapat berpikir jernih yaitu keluarga dari pihak korban maupun keluarga dari pihak pelaku, sistem ini digunakan di New Zealand dan disebagian negara bagian Australia.

3. Police-Led conferencing yaitu pengembangan dari dua sistem di atas, dengan memasukkan pihak yang memiliki posisi netral yang tidak mewakili kepentingan korban ataupun pelaku, melainkan kepentingan umum karena dalam mediasi sebelumnya baik secara individu ataupun secara kolektif melalui peranan keluarga, para pihak yang terlibat mediasi tidaklah benar-benar netral secara murni. Sebagai contoh pihak keluarga korban tentu akan berpihak kepada korban dan sebaliknya pihak keluarga pelaku tentu saja akan berpihak secara penuh kepada pelaku. Sehingga dalam hal ini tidak ada pihak tengah yang dapat memberikan keyakinan kepada kedua belah pihak akan adanya win-win solution, pihak penengah yang diyakini pantas untuk menempati posisi tersebut adalah polisi, hal ini dikarenakan polisi adalah pihak pertama yang bersinggungan langsung dengan pelaku dan korban setelah terjadinya suatu tindak pidana, dalam hal ini polisi dapat memberikan solusi yang bertujuan dapat memulihkan kerugian korban tanpa harus menghukum pelaku, sehingga apabila perkara-perkara tertentu dapat diselesaikan maka polisi dapat fokus dalam menangani perkara-perkara lain yang memerlukan penanganan ekstra, tidak hanya itu apabila perkara tersebut diselesaikan di luar pengadilan maka secara tidak langsung juga selain memenuhi rasa keadilan, juga dapat mengurangi over load penjara, dimana pelaku kejahatan tidak selalu berakhir dipenjara, selama pelaku berjanji tidak akan mengulangi perbuatannya dan mengganti kerugian akibat perbuatannya maka pelaku tidak perlu untuk dihukum.

Peranan penegak hukum seperti polisi dalam hal ini amatlah diperlukan selaku pihak perantara dan penengah dalam mediasi antara pihak korban dan pelaku, karena apabila tidak ada yang menjembatani dan menengahi maka sulit untuk tercapai titik temu yang menyajikan win-win solution bagi masing-masing pihak. Selain itu mengingat pengalaman dari polisi dalam menangani segala macam kejahatan maka dimungkinkan pula dapat mempertemukan dua kepentingan yang berbeda tersebut sehingga dapat memungkinkan tercapainya restorative justice diantara kedua belah pihak yaitu korban dan pelaku, adapaun sistem ini diterapkan disebagian negara bagian Amerika Serikat dan sebagian negara bagian Australia, yang dimasukkan dalam proses pre-trial, yaitu proses sebelum dimulainya Persidangan dihadapan hakim, apabila dalam hal ini tercapai kesepakatan maka tidak perlu dilakukan trial, namun demikian apabila tidak tercapai kesepakatan maka kasus tersebut akan diselesaikan oleh hakim dihadapan pengadilan.

4. Reparation Board adalah metode baru yang tidak hanya melibatkan polisi, korban dan pelaku dalam proses mediasi penyelesaian perkara, namun dilakukan dengan pembentukan suatu dewan masyarakat (citizen panel), yang berusaha mempertemukan keinginan pelaku dan korban dengan melibatkan keluarga korban, ataupun pihak 
Nommensen Journal of Legal Opinion (NJLO)

Jurnal Magister Hukum Program Pascasarjana Universitas HKBP Nommensen

Volume o1 Nomor o1 Juli 2020 Halaman. 64-77

e-ISSN: 2723-164X p-ISSN: 2722-9858

http://ejournal.uhn.ac.id/index.php/opinion

kepolisian. Dalam hal ini dewan tersebut akan menilai tindakan yang dilakukan pelaku, kemudian kerugian yang ditimbulkannya yang nantinya akan dibawa dihadapan korban, dalam hal ini korban akan memutuskan apakah akan menerima penilaian dari dewan tersebut atau tidak. Dalam hal korban memutuskan untuk menerima keputusan dewan maka kasus tersebut akan dianggap selesai karena korban dianggap telah memaafkan si pelaku dan si pelaku berkewajiban untuk mengganti segala kerugian yang ditimbulkannya. Namun sebaliknya pula apabila dalam hal ini korban tidak menerima penilaian dari dewan, maka korban dianggap belum memaafkan pelaku dan pelaku tetap akan dihukum melalui proses persidangan yang nantinya akan diputuskan oleh hakim, dalam hal ini konsekuensinya korban kerugiannya tidak terpulihkan dan pelaku tetap akan dihukum. Tipe ini adalah tipe baru sebagai bentuk pengembangan lebih lanjut dari upaya penyelesaian perkara pidana melalui restorative justice, pembentukan dewan tersebut tidak hanya murni sebagai dewan yang bertugas menyelesaikan perkara melalui restorative justice, namun juga sebagai suatu lembaga yang terus mengsosialisasikan restorative justice bagi setiap warga negara, karena tidak jarang masyarakat tidak mengetahui adanya restorative justice ini dan masih tetap terpaku pada konsep keadilan retributif yang mengedepankan pemberian hukuman kepada setiap pelaku kejahatan, padahal terhadap kejahatan harta benda keadilan retributif tidak dapat memulihkan kerugian korban secara maksimal, sementara itu melalui restorative justice kerugian korban dapat dipulihkan secara maksimal. Adapun negara yang menganut sistem ini adalah Negara Wales yang menjadi bagian dari United Kingdom of Britain atau Britania Raya.

Berdasarkan empat tipe penyelesaian sengketa melalui restorative justice yang diterapkan dibeberapa negara tersebut maka, tipe penyelesaian perkara melalui restorative justice yang dapat diterapkan di Indonesia, adalah kombinasi dari dua tipe, yaitu kombinasi antara victim offender mediation dan police-led conferencing, kombinasi dua tipe ini adalah tipe yang paling sempurna, hal ini dikarenakan adanya beberapa alasan yang antara lain adalah sebagai berikut. Pertama, bahwa kedua tipe tersebut dapat mengakomodasi para pihak yang terlibat dalam perkara tindak pidana ringan, yaitu pelaku, korban dan polisi. Kedua, bahwa polisi dalam hal ini adalah pihak pertama yang berhadapan dengan tindak pidana ringan dapat memperkenalkan upaya penyelesaian sengketa melalui restorative justice kepada korban dan pelaku, apabila korban dan pelaku dapat menyelesaikan persoalannya melalui restorative justice maka, pihak kepolisian dapat lebih fokus dan terhadap perkara-perkara lain yang lebih membutuhkan penanganan ekstra. Ketiga, bahwa kepentingan kedua belah pihak yaitu korban dan pelaku, dapat dipertemukan oleh pihak kepolisian sehingga dapat mempermudah pencapaian win-win solution terhadap perkara tindak pidana ringan tersebut. Keempat, bahwa pihak kepolisian sebagai pihak yang netral dapat berperan sebagai penengah dalam mediasi yang dilakukan oleh korban dan pelaku. Kelima, bahwa korban dan pelaku dapat memberikan tawar menawar yang saling menguntungkan dalam mediasi tersebut, sehingga pelaku tidak perlu dihukum dan kerugian korban dapat dipulihkan. Keenam, bahwa dengan adanya bargaining position antara korban dan pelaku, yang difasilitasi oleh kepolisian, maka pencapaian restorative justice bagi kedua belah pihak akan lebih terjamin.

Proses restorative justice menempatkan kejahatan sebagai gejala yang menjadi bagian tindakan sosial dan bukan sekedar pelanggaran hukum pidana. Kejahatan dipandang sebagai tindakan yang merugikan orang dan merusak hubungan sosial. Berbeda dengan hukum pidana yang telah menarik kejahatan sebagai masalah negara. Dalam hal ini negara berhak menghukum, meskipun sebenarnya komunitas adat bisa saja memberikan sanksi tertentu. Sistem pemenjaraan sebagai pembalasan diterima dan dijalankan negara, dalam hal ini 
restorativejustice dalam proses pidana sering dianggap belum memberikan keadilan pada korban. Namun demikian usaha ke arah restorative justice sebenarnya sudah ada di lembaga pemasyarakatan, misalnya penerapan menempatkan masa pembinaan sebagai ajang menyetarakan kembali hubungan narapidana dan korban. Untuk itu bentuk hukuman restoratif diperkenalkan karena sistem peradilan pidana dan pemidanaan yang sekarang berlaku masih menimbulkan masalah. Dalam sistem kepenjaraan sekarang tujuan pemberian hukuman adalah penjeraan, pembalasan dendam, pemberian derita sebagai konsekuensi perbuatannya. Indikator penghukuman diukur dari sejauh mana narapidana (napi) tunduk pada peraturan penjara. Jadi, pendekatannya lebih ke keamanan (security approach). Pemenjaraan membawa akibat bagi keluarga napi, sistem yang berlaku sekarang dinilai tidak melegakan atau menyembuhkan korban. Apalagi, proses hukumnya memakan waktu lama. Sebaliknya, pemidanaan restoratif melibatkan korban, keluarga dan pihak-pihak lain dalam menyelesaikan masalah. Di samping itu, menjadikan pelaku tindak pidana bertanggung jawab untuk memperbaiki kerugian yang ditimbulkan akibat perbuatannya, terhadap korban penekanannya adalah pemulihan kerugian aset, derita fisik, keamanan, harkat dan kepuasan atau rasa keadilan. Bagi pelaku dan masyarakat, tujuannya adalah pemberian malu agar pelaku tidak mengulangi lagi perbuatannya, dan masyarakat pun menerimanya.

\section{Model Alternatif Yang Dapat Dilakukan Dalam Penyelesaian Tindak Pidana Biasa Bermotif Ringan Sebagai Upaya Pembaharuan Hukum Pidana.}

Adapun model alternatif penyelesaian tindak pidana biasa bermotif ringan dapat dilakukan sebagai salah satu upaya untuk melakukan pembaharuan hukum pidana dimasa mendatang adalah : setidaknya terdapat 2 (dua) model dianggap dapat memenuhi rasa keadilan bagi pelaku, korban dan masyarakat, yakni:

\section{Model formal dengan mengintegrasikan Restorative Justice}

Penyelesaian kasus tindak pidana pada dasarnya tidak harus dimonopoli oleh model tunggal berupa proses peradilan pidana yang bekerja dalam kerangka sistem peradilan pidana (criminal justice system) manakala model tersebut sudah tidak memuaskan lagi bagi masyarakat banyak. Berkaitan dengan hal tersebut, saat ini secara faktual masyarakat menghendaki penyelesaian perkara tindak pidana secara kekeluargaan dengan mengesampingkan kaidah normatif. Model ini apabila dikonstruksikan dalam suatu model dalam victimology maka ditemukan suatu model yang dikenal dengan Restorative justice.

Restorative Justice adalah suatu respon terhadap tindak pidana yang menitik beratkan pada pemulihan korban yang menderita kerugian, memberikan pengertian kepada pelaku untuk bertanggung jawab atas tindak pidana yang mereka lakukan, dan membangun masyarakat yang damai. Restorative Justice dapat digambarkan sebagai suatu tanggapan kepada perilaku kejahatan untuk memulihkan kerugian yang diderita oleh para korban kejahatan dan untuk memudahkan perdamaian antar pihak-pihak yang saling bertentangan. ${ }^{22}$

Hakikat restoratif justice tak lain adalah nilai yang terkandung di dalamnya di mana telah mencerminkan ruh dari nilai Pancasila yakni "musyawarah". Berdasarkan hal tersebut, restoratif justice pun pada dasarnya telah diwujudkan oleh beberapa masyarakat hukum adat dalam pencerminan nilai musyawarah, sehingga esensi dari konsep restoratif justice bukanlah suatu konsep yang baru. Penggunaan model formal dengan mengintegrasikan restorative justice secara yuridis telah mendapatkan pengakuan dengan diakomodisirnya restorative

\footnotetext{
${ }^{22}$ Kevin I. Minor and J. T. Morrison. 1996. “A Theoretical Study and Critique of Restorative Justice.” In Restorative Justice: International Perspectives, edited by Burt Galaway and Joe Hudson. Monsey, NY; Amsterdam, The Netherlands: Criminal Justice Press and Kugler Publications, page. 117.
} 
justice dalam penegakan hukum tindak pidana ringan, yakni dengan dibentuknya Nota Kesepakatan Bersama Ketua Mahkamah Agung Republik Indonesia, Menteri Hukum dan HAM Republik Indonesia, Jaksa Agung Republik Indonesia, dan Kepala Kepolisian Negara Republik Indonesia tentang Pelaksaan Penerapan Penyusunan Batasan Tindak Pidana Ringan dan Jumlah Denda, Acara Pemeriksaan Cepat, Serta Penerapan Keadilan Restoratif (Restorative Justice), Nomor: 131/ KMA/SKB/X/2012; Nomor: M. HH -07. HM. 03.02 Tahun 2012; Nomor: KEP - 06/E/EJP/10/2012; Nomor: B/39/X/2012, Rabu tanggal 17 Oktober 2012.

Pengertian restorative justice telah diatur dalam Pasal 1 ayat (2) Nokesber, bahwa keadilan restoratif (restorative justice) adalah "penyelesaian perkara tindak pidana ringan yang dilakukan oleh penyidik pada tahap penyidikan atau hakim sejak awal persidangan dengan melibatkan pelaku, korban, keluarga pelaku/korban, dan tokoh masyarakat terkait untuk bersama-sama mencari penyelesaian yang adil dengan menekankan pemulihan kembali pada keadaan semula". Pengaturan lebih lanjut mengenai restorative justice, sebagaimana di atur dalam Pasal 4, bahwa:

1. Penyelesaian perkara Tindak Pidana Ringan melalui Keadilan Restoratif dapat dilakukan dengan ketentuan telah dilaksanakan perdamaian antara pelaku, korban, keluarga pelaku/korban, dan tokoh masyarakat terkait yang berpekara dengan atau tanpa ganti kerugian;

2. Penyelesaian perkara Tindak Pidana Ringan melalui Keadilan Restoratif sebagaimana dimaksud pada ayat (1) dilakukan oleh Penyidik Kepolisian atau Hakim;

3. Perdamaian antara para pihak yang berperkara dikukuhkan dalam kesepakatan tertulis;

4. Keadilan Restoratif sebagaimana dimaksud pada ayat (1) tidak berlaku pada pelaku tindak pidana yang berulang sesuai dengan ketentuan peraturan perundang-undangan.

Berdasarkan uraian diatas maka penggunaan restorative justice tidak perlu diragukan dalam penegakan hukum tindak pidana ringan, mengingat telah diakui dan diatur dalam Nokesber. Namun demikian, pengaturan mengenai restorative justice dalam tindak pidana ringan sebaiknya diatur lebih lanjut dalam norma hukum yang memiliki kedudukan lebih tinggi. Adapun alternatif lain, jika Nokesber telah dianggap cukup mampu sebagai payung hukum penggunaan restorative justice dalam perkara tindak pidana ringan, maka hal utama yang harus dilakukan adalah sosialisasi Nokesber tersebut tidak hanya tertuju dikalangan aparat penegak hukum, melainkan juga perlu dilakukan sosialisasi terhadap seluruh lapisan masyarakat. Mengingat, pada dasarnya sosialisasi telah diatur dalam Pasal 9 Nokersber, bahwa "Para pihak wajib melakukan sosialisasi Nota Kesepakatan Bersama ini kepada pemerintah, swasta, perguruan tinggi, dan masyarakat", namun demikian secara realita sosialisasi Nokerbes ini belum mencapai secara meluas baik terhadap swasta, perguruan tinggi, maupun masyarakat.

Mengoptimalkan Lembaga Adat yang Dimiliki oleh Beberapa Daerah

Sebagai suatu alternatif dalam penyelesaian perkara tindak pidana ringan, tentunya dibutuhkan suatu langkah yang inovatif yakni dengan mengoptimalkan lembaga adat yang dimiliki oleh beberapa daerah. Adapun terdapat beberapa alasan :

1. Penyelesaian secara adat lebih dapat dirasakan nilai keadilannya, di mana hal itu tumbuh dan berakar pada nilai keadilan masyarakat setempat yang sudah terinternalisasi dan diakui eksistensinya (diterima daya berlakunya). Hal ini sebagaimana terlihat secara empiris bahwa budaya konsiliasi atau musyawarah merupakan nilai masyarakat yang meluas di secara damai telah lama dan biasa digunakan dan dianggap mampu menghilangkan perasaan dendam, serta berperan menciptakan keamanan, ketertiban, dan perdamaian. 
2. Jangkauan aparat penegak hukum yang bergerak melalui sistem peradilan terbatas, di mana dengan melihat keadaan geografis Indonesia yang sangat luas dan masih minimnya fasilitas pada daerah terpencil tentunya aparat penegak hukum belum tentu sepenuhnya mampu untuk menjangkau dengan waktu yang cepat dan hasil optimal, sehingga dapat terjadi konsekuensi penumpukan perkara. Ketiga, dapat menekan biaya yang mahal yang harus dikeluarkan bagi pencari keadilan maupun negara selama proses penyelesaian perkara tindak pidana.

3. Dapat menekan biaya yang mahal yang harus dikeluarkan bagi pencari keadilan maupun negara selama proses penyelesaian perkara tindak pidana.

Adapun apabila dilihat secara normatif, maka ketentuan normatif sebagaimana dirumuskan dalam Pasal (1) angka (10) Undang-undang No. 30 Tahun 1999 tentang Arbitrase dan Alternatif Penyelesaian Sengketa, disebutkan bahwa masyarakat dimungkinkan memakai alternatif lain dalam melakukan penyelesaian sengketa. Implementasinya dapat berbagai macam antara lain dengan konsultasi, negosiasi, mediasi, konsiliasi serta penggunaan mekanisme peradilan adat. Mekanisme ini (peradilan adat) masih berlaku di daerah-daerah pedalaman di banyak negara di dunia. Hal ini terjadi beberapa hal, antara lain:

1. Terbatasnya akses masyarakat terhadap sistem hukum formal yang ada;

2. Masyarakat tradisional di daerah terisolasi pada dasarnya masih memiliki tradisi hukum yang kuat berdasarkan hukum tradisionalnya dalam memecahkan permasalahan hukum yang terjadi. Hal ini merupakan realitas dimana tradisi atau "custom" masih berlaku di banyak tempat. Ini juga merupakan realita dimana perubahan masyarakat kadang kala terbentur batas wilayah, dan bahwa hal ini juga merupakan kenyataan dimana terdapat daerah-daerah yang masih "steril" keberlakukan sistem hukum formal;

3. Tipe pemecahan masalah yang ditawarkan sistem hukum formal terkadang memperoleh pandangan yang berbeda dan dianggap kurang memadai dan kurang memenuhi rasakeadilan masyarakat yang masih memegang tradisi hukum mereka sendiri;

4. Kurang memadainya infrastruktur dan sumber daya yang dimiliki oleh sistem hukum formal menyebabkan kurangnya daya adaptasi dalam menyerap kebutuhan rasa keadilan masyarakat setempat.

Penyelesaian sengketa damai telah lama dan biasa digunakan oleh masyarakat. Hal ini dapat dilihat dari hukum adat yang menempatkan kepala adat sebagai penengah dan memberi putusan adat bagi sengketa di antara warga. Berbagai suku bangsa di Indonesia mempunyai budaya penyelesaian sengketa secara damai, misalnya masyarakat Jawa, Bali, Sulawesi Selatan, Sulawesi Tengah, Sumatera Barat, Dayak, Sumatera Selatan, Lampung, Lombok, Irian Jaya, dan masyarakat Toraja. Bentuk penyelesaiannya maupun tingkat kekuatan mengikat dari hasil penyelesaian perkara tindak pidana tentunya bervariasi, sesuai dengan hukum adat yang bersangkutan. Adapun makna yang dapat diambil adalah nilai-nilai ketuhanan (memaafkan) dan musyawarah yang terkandung di dalamnya, yang tidak lain merupakan pencerminan nilainilai Pancasila.

\section{D.Kesimpulan}

Penyelesaian tindak pidana biasa bermotif ringan dengan model restorative justice, dapat dilakukan jika syarat -syarat restorative justce telah terpenuhi antara lain pelaku telah mengakui perbuatannya dan menunjukkan rasa penyesalan yang mendalam, korban dan atau keluarga korban berkeinginan untuk memaafkan pelaku. Selain itu kelompok masyarakat mendukung dilakukannya musyawarah, terutama perbuatan itu memenuhi kualifikasi tindak pidana ringan. Jika hal tersebut terpenuhi maka aparat penegak hukum seperti Kepolisian dapat melakukan pendekatan restorative 
Jurnal Magister Hukum Program Pascasarjana Universitas HKBP Nommensen

Volume o1 Nomor o1 Juli 2020 Halaman. 64-77

e-ISSN: 2723-164X p-ISSN: 2722-9858

http://ejournal.uhn.ac.id/index.php/opinion

justice melalui forum mediasi penal diruang mediasi selama berlangsungnya proses pemeriksaan. Tujuan kesemuanya dilakukan adalah untuk diperolehnya asas keseimbangan di dalam masyarakat. Pengoptimalan lembaga adat yang dimiliki beberapa daerah, sangat mendukung untuk dilakukannya restorative Justice. Model ini dirasakan keadilannya, hal itu disebabkan di dalam masyarakat Indonesia telah terinternalisasi dan diakui eksistensinya.

\section{Daftar Pustaka}

Barda Nawawi Arief ,1996, Kebijakan Legislatif Dengan Pidana Penjara, UNDIP, Semarang

G. Wediartana, 2014, Viktimologi Perspektif Korban Dalam Penanggulangan Kejahatan, Cahaya Atma Pustaka, Yogyakarta.

John M.Scheb JD dan John M.Scheb II, 2008, Criminal Law and Procedure, Sixt Edition, Thomson Laerning, Belmont.

Kevin I.Minor and J.T Morrison, 1996, A Theoretical Study and Critique of Restorative Justice" In Restorative Justice; International Perspective, edited by Burt Galaway and Joe Hudson; Criminal Justice Press and Kugler Publications, The Netherlands.

Moelyatno, 2000, Asas-Asas Hukum Pidana, Cet ke 6,Jakarta, Rineka Cipta

Marlina , 2010, Hukum Penitensier, Refika Aditama, Jakarta

Retna Yuli, 2010, Viktimologi Perlindungan Hukum Terhadap Korban Kejahatan, Graha Ilmu, Bandung.

Sudarto, 1975, Hukum Pidana, Alumi, Bandung.

Suratman dan Philips Dillah, 2013, Metode Penelitian Hukum, Alfabeta, Bandung

Solly Lubis, 2012, Filsafat Ilmu dan Penelitian, Sofmedia, Medan

Simamora, Janpatar. "Tafsir Makna Negara Hukum dalam Perspektif Undang-Undang Dasar Negara Republik Indonesia Tahun 1945." Jurnal Dinamika Hukum 14, No. 3 (2014): 547561.

Simamora, Janpatar., Development of Constitutional Interpretation by Constitutional Court of Indonesia in the Context of State Institutions' Authority Dispute Settlement, IOSR Journal Of Humanities And Social Science (IOSR-JHSS) Volume 24, Issue 12, Series. 3 (December. 2019) 45-54.

Wirjono Prodjodikoro, 1989, Asas-Asas Hukum Acara Pidana di Indonesia, Cet ke 3 Bandung, Erisco

R.Soesilo, 1998, Kitab Undang-Undang Hukum Pidana (KUHP) Serta Komentar-Komentarnya Lengkap Pasal Demi Pasal, Politea Bogor.

http://www.hukumonline.com/berita/baca/lt524025679ffe/ma-keluhkan-pelaksanaan-permatipiring, diakses pada hari Kamis, Tanggal 18 Juni 2020, Jam 22.30. 